\title{
KEEFEKTIFAN PENGGUNAAN MEDIA GAMBAR PUZZLE DALAM KETERAMPILAN MENULIS KALIMAT SEDERHANA BAHASA JERMAN SISWA KELAS XI MAN 1 MAKASSAR
}

\author{
Sunarti ${ }^{1}$ dan Ambo Dalle ${ }^{2}$ \\ Program Pascasarjana Universitas Negeri Makassar ${ }^{1}$ \\ Fakultas Bahasa dan Sastra Universitas Negeri Makassar ${ }^{2}$ \\ Email ${ }^{1}$ : sunartijumardi@gmail.com
}

\begin{abstract}
ABSTRAK
Tujuan penelitian ini untuk memeroleh data dan informasi tentang keefektifan penggunaan media gambar puzzle dalam keterampilan menulis kalimat sederhana bahasa Jerman siswa kelas XI MAN 1 Makassar. Desain penelitian ini adalah True Eksperimen (two grouppretest-posttestdesign). Populasi penelitian adalah siswa kelas XI MAN 1 Makassar. Sampel dalam penelitian dipilih secara acak (random sampling) yakni siswa kelas XI IPA 1 sebagai kelas eksperimen dan siswa kelas XI IPA 3 sebagai kelas kontrol. Data dianalasis dengan menggunakan analisis Uji-t. Hasil analisis data menunjukkan bahwa $t_{h} 6,134>t_{t} 2,003$ pada taraf signifikan 0,05 . Hasil penelitian menunjukkan bahwa penggunaan media gambar puzzle efektif dalam keterampilan menulis kalimat sederhana bahasa Jerman siswa kelas XI MAN 1 Makassar.
\end{abstract}

Kata Kunci: Efektivitas, Media Gambar Puzzle, KeterampilanMenulis Kalimat Sederhana

\begin{abstract}
The purpose of this research was to gain data and information about the effectiveness of puzzle picture media in German language simple sentence writing skill of student in class XI MAN 1 Makassar. Research design was true experiment (two grouppretestposttestdesign). Population was students in class XI MAN 1 Makassar which divided into 4 classes. Sampel was students in class XI IPA 1 as eksperiment class and XI IPA 3 as control class. They were selected by randomly. Data was analysed by using t-test. The result showed that $t_{h} 6,134>t_{t} 2,003$ on the significance level 0,05 . It means that the use of this media is effective in German language simple sentence writing skill of student.
\end{abstract}

Keywords: Effectiveness, Puzzle Picture Media, Writing Skill, and Simple Sentence

\section{PENDAHULUAN}

Tujuan pengajaran bahasa asing di tingkat SMA dan sederajat, yaitu untuk meningkatkan kompetensi berbahasa asing siswa dalam empat aspek, yaitu keterampilan menulis, kemampuan membaca, kemampuan menyimak, keterampilan berbicara serta aspek penunjang, yaitu penguasaan tata bahasa dan kosakata. Salah satu kompetensi berbahasa yang sangat penting dalam pembelajaran bahasa asing adalah keterampilan menulis karena saat menulis, siswa harus memerhatikan kaidah-kaidah bahasa Jerman, penguasaan kosakata, tanda baca, dan kemampuan 
menyusun kalimat serta mengungkapkan ide atau gagasan dalam bentuk kalimat.

Salah satu media yang dapat dijadikan alat pendukung dalam peningkatan keterampilan menulis adalah media gambar puzzle. Penerapan media puzzle dapat menciptakan kreativitas dan tidak membosankan, melatih siswa berpikir logis, mengembangkan ide siswa, membantu siswa untuk memahami suatu persoalan dengan mudah dan cepat.

Penelitian terdahulu yang memiliki relevansi dengan permasalaham pembelajaran keterampilan menulis, antara lain dilakukan oleh Rapang (2012:51) menunjukkan bahwa keterampilan menulis bahasa Jerman siswa kelas X.8 SMAN 3 Makale Tana Toraja termasuk dalam kategori rendah $(56,28 \%)$. Selanjutnya, penelitian yang dilakukan oleh Taro (2008:33) menunjukkan bahwa keterampilan menyusun kalimat bahasa Jerman siswa kelas XI SMA 1 Anggeraja Kabupaten Enrekang masih dalam kategori rendah (59,2\%). Demikian pula yang dilakukan oleh Haerani (2013:47) mengemukakan bahwa kemampuan menulis kalimat sederhana bahasa Jerman melalui media gambar siswa kelas XI SMA 1 Bontonompo Kabupaten Gowa termasuk dalam kategori baik $(75,28)$.

\section{MEDIA GAMBAR PUZZLE}

Media gambar puzzle merupakan media permainan yang memudahkan anak secara bertahap untuk mengembangkan kemampuan mereka dalam memecahkan masalah, dan untuk mengetahui akan tempattempat permainan yang sesuai serta mengajarkan anak untuk bertindak cermat. Dengan puzzle dapat melatih anak untuk mengingat-ingat, berimajinasi dan menyimpulkan.

Pembelajaran menggunakan puzzle, memberikan manfaat siswa untuk berpikir secara nyaman melalui permainan untuk menyelesaikan masalah yang berhubungan dengan materi pelajaran yang masih dipelajari. Proses belajar memecahkan masalah memerlukan suatu pengamatan secara cermat dan lengkap. Istilah puzzle ini oleh masyarakat Indonesia dikenal sebagai permainan bongkar pasang. Puzzle merupakan salah satu media yang bisa juga digunakan untuk mengenalkan bangun datar sederhana, seperti persegi, persegi panjang, segitiga, dan lingkaran. Puzzle sebagai alat untuk permainan yang mengharuskan kita sebagai pemain menyusun potongan-potongan puzzle.

$$
\text { Menurut Patmonodewo }
$$

(dalam Misbach, Muzamil, 2010), kata puzzle berasal dari bahasa Inggris yang berarti teka-teki atau bongkar pasang, media puzzle merupakan media sederhana yang dimainkan dengan bongkar pasang. Sedangkan, Jamil (2012:2) mengemukakan bahwa puzzle merupakan bentuk teka-teki dengan model menyusun potongan-potongan gambar menjadi kesatuan gambar yang utuh.

$$
\text { Selanjutnya, menurut }
$$

Rahmanelli (2007:24), puzzle adalah 
permainan merangkai potonganpotongan gambar yang berantakan menjadi suatu gambar yang utuh. Sedangkan, Ismail (2012:199) mengemukakan bahwa puzzle adalah permainan yang menyusun suatu gambar atau benda yang telah dipecah dalam beberapa bagian. Buttner (2013:173) menambahkan bahwa puzzle kosakata merupakan sarana yang sangat bermanfaat untuk mempelajari kembali kosakata, gramatikal, kebudayaan, dan topik berdasarkan konten. Berdasarkan pengertian tentang media puzzle, maka dapat disimpulkan bahwa media puzzle merupakan alat permainan edukatif yang dapat merangsang kemampuan anak, yang dimainkan dengan cara membongkar pasang kepingan puzzle berdasarkan pasangannya.

Nani (2008) mengemukakan bahwa pada umumnya, sisi edukasi permainan puzzle ini berfungsi untuk:

1. Melatih konsentrasi, ketelitian, dan kesabaran

2. Melatih koordinasi mata dan tangan. Anak belajar mencocokkan keping-keping puzzle dan menyusunnya menjadi satu gambar

3. Memperkuat daya ingat

4. Mengenalkan anak pada konsep hubungan

5. Dengan memilih gambar/bentuk, dapat melatih anak untuk berpikir matematis (menggunakan otak kiri)

6. Melatih logika anak. Misalnya, puzzle bergambar manusia. Anak dilatih menyimpulkan di mana letak kepala, tangan, dan kaki sesuai logika

Teori yang berbeda dikemukakan oleh Rochmani (2011:18) bahwa proses pembelajaran menggunakan media gambar dapat dilakukan dengan langkah sebagai berikut: (1) Kegiatan awal, terdiri dari salam pembuka, dan menjelaskan tujuan pembelajaran; (2) kegiatan inti, guru menunjukkan gambar kepada siswa dan memberikan contoh pelafalan yang tepat; (3) penutup, guru menginformasikan kepada siswa tentang kesimpulan pembelajaran.

Berikut ini ada beberapa jenis puzzle yang dapat digunakan untuk meningkatkan kemampuan memahami kosakata:

1. Spelling puzzle, yaitu puzzle yang terdiri dari gambar-gambar dan huruf-huruf acak untuk dijodohkan menjadi kosakata yang benar.

2. Jigsaw puzzle, yaitu puzzle yang berupa beberapa pertanyaan untuk dijawab kemudian dari jawaban itu diambil huruf-huruf pertama untuk dirangkai menjadi sebuah kata yang merupakan jawaban pertanyaan yang paling akhir.

3. The thing puzzle, yaitu puzzle yang berupa deskripsi kalimat-kalimat yang berhubungan dengan gambar-gambar benda untuk dijodohkan.

4. The letter(s) readiness puzzle, yaitu puzzle yang berupa gambargambar disertai dengan hurufhuruf nama gambar tersebut, tetapi huruf itu belum lengkap.

5. Crosswords puzzle, yaitu puzzle yang berupa pertanyaan- 
pertanyaan yang harus dijawab dengan cara memasukan jawaban tersebut ke dalam kotak-kotak yang tersedia baik secara horizontal maupun vertikal.

\section{METODE PENELITIAN}

Penelitian ini menggunakan dua variabel, yaitu variabel bebas dan variabel terikat. Variabel bebas (X) adalah penggunaan media gambar puzzle dan variabel terikat (Y) adalah keterampilan menulis kalimat sederhana bahasa Jerman siswa kelas XI MAN 1 Makassar. Desain penelitian yang digunakan dalam penelitian ini adalah true experimental design dengan bentuk two group pretest-posttest design. Pengukuran variabel dalam penelitian, ini yaitu dengan memberikan tes membuat kalimat sederhana bahasa Jerman melalui media gambar untuk mengetahui tingkat kemampuan siswa dalam menulis kalimat sederhana bahasa Jerman.

Populasi dalam penelitian ini adalah siswa kelas XI IPA MAN 1 Makassar yang terdiri atas 4 kelas dengan jumlah keseluruhan 112 siswa. Sampel yang digunakan dalam penelitian ini berjumlah 58 orang yakni kelas XI IPA 1 sebagai kelas eksperimen yang berjumlah 29 orang dan kelas XI IPA 3 sebagai kelas kontrol yang berjumlah 29 orang yang dipilih secara acak (random sampling). Teknik pengumpulan data dalam penelitian ini menggunakan instrumen sebagai berikut: Tes awal (Pretest), yaitu tes yang diberikan kepada siswa di awal penelitian yang bertujuan untuk mengetahui tingkat kemampuan awal siswa dalam pembelajaran bahasa Jerman. Tes akhir (Posttest), yaitu tes esai tentang menulis kalimat sederhana yang diberikan kepada siswa setelah diajar. Tes ini bertujuan untuk mengetahui sejauh mana tingkat pencapaian siswa setelah penerapan media gambar puzzle dalam pembelajaran bahasa Jerman.Bentuk pretest dan posttest pada penelitian ini adalah esai yang berjumlah masing-masing 20 nomor.

Teknik analisis data dalam penelitian ini menggunakan analisis statistika deskriptif dan inferensial untuk menguji hipotesis penelitian dengan menggunakan uji-t. Sebelum melakukan pengujian tersebut terlebih dahulu dilakukan uji normalitas dengan menggunakan tabel Z-score, chi kuadrat, dan uji homogenitas dengan menggunakan uji F (Fisher). Sebelum menentukan uji normalitas data dan homogenitas maupun uji hipotesis terlebih dahulu tentukan nilai rata-rata (mean), simpangan baku dan varian.

\section{PEMBAHASAN}

Pada penelitian ini, pembelajaran dilakukan selama 4 kali pertemuan. Dalam pembelajaran tersebut, kedua kelas diajar menggunakan teknik yang berbeda.Pada kelas eksperimen siswa diajar dengan menggunakan media gambar puzzle dalam keterampilan menulis bahasa Jerman sedangkan pada kelas kontrol diajar dengan tidak menggunakan media gambar puzzle. 
Dalam hal ini menggunakan metode ceramah dan tanya jawab.

Hasil pre-test menunjukkan bahwa nilai rata-rata (mean) untuk kelas eksperimen 84,18 dan kelas kontrol adalah $\mathbf{7 5}$ dalam keterampilan menulis kalimat sederhana bahasa Jerman siswa kelas XI IPAMAN 1 Makassar, jumlah skor perolehan untuk kelas eksperimen adalah 2441 dan kelas kontrol adalah 2175. Hasil uji normalitas pada data pre-test pada kedua kelas menunjukkan bahwa kelas eksperimen dan kontrol memiliki chikuadrat hitung masing-masing lebih kecil dari chi-kuadrat tabel, $\chi_{\text {hitung }}<\chi_{\text {tabel }}$, dimana pre-test kelas eksperimen $(-69,82<11,07)$ dan pretest kelas kontrol $(-42,07<11,07)$, sehingga distribusi data pre-test dinyatakan normal, artinya tes yang diberikan sesuai dengan kemampuan siswa.

Berdasarkan hasil post-test kelas eksperimen, penggunaan media gambar puzzle berdampak positif pada peningkatan keterampilan menulis kalimat sederhana bahasa Jerman siswa. Hal tersebut dapat dilihat dari perolehan nilai post-test siswa, pada kelas eksperimen nilai terendah yaitu 77 dan nilai tertinggi 98 dengan nilai rata-rata 84,18 , sedangkan pada kelas kontrol diperoleh nilai 60 untuk nilai terendah dan 84 untuk nilai tertinggi dengan nilai rata-rata 75. Selain itu, tingkat keterampilan menulis kalimat sederhana bahasa Jerman siswa dalam mengerjakan soal pre-test pada kelas eksperimen $\quad(53,38 \%) \quad$ setelah diberikan perlakuan, persentasenya lebih meningkat sebesar 30,80\% yakni
(84,18\%) dibandingkan kelas kontrol yang tidak diberikan perlakuan. Sehingga, media gambar puzzle dianggap cukup membantu dalam keterampilan menulis kalimat sederhana bahasa Jerman siswa.

Hasil analisis di atas, dilanjutkan dengan uji-t untuk melihat hasil akhir dari penelitian ini. Hasilnya adalah $t_{\text {hitung }}=6,134$ sementara $t_{\text {tabel }}=2,003$, jadi $t_{\text {hitung }} \geq$ $\left.t_{\text {tabel }}(6,134) \geq 2,003\right)$. Dengan demikian, $\mathrm{H}_{1}$ yang menyatakan bahwa ada perbedaan keefektifan yang signifikan antara antara keterampilan menulis kalimat sederhana bahasa Jerman siswa yang diajar dengan menggunakan media gambar puzzledan siswa yang tidak diajar dengan menggunakan media gambar puzzlekelas XI IPA MAN 1 Makassar dinyatakan diterima dan $\mathrm{H}_{0}$ yang menyatakan bahwa tidak ada perbedaan keefektifan yang signifikan antara antara keterampilan menulis kalimat sederhana bahasa Jerman siswa yang diajar dengan menggunakan media gambar puzzle dan siswa yang tidak diajar dengan menggunakan media gambar puzzle kelas XI IPA MAN 1 Makassar ditolak. Oleh karena itu, dapat disimpulkan bahwa penelitian tentang keefektifan penggunaan media gambar puzzle dalam keterampilan menulis kalimat sederhana bahasa Jerman siswa kelas XI IPA MAN 1 Makassar dinyatakan berhasil.

Keefektifan penggunaan media gambar puzzle dalam keterampilan menulis kalimat sederhana bahasa Jerman siswa kelas 
XI IPA MAN 1 Makassar juga dapat dilihat pada hasil analisis post-test siswa. Hasil analisis post-test pada kelas eksperimen (XI IPA 1) dengan jumlah 29 orang siswa menunjukkan bahwa terdapat $11(38 \%)$ orang siswa memperoleh nilai terendah berada pada interval skor 77-80. Rendahnya pencapaian nilai tersebut disebabkan karena siswa masih keliru menulis penulisan kata benda (Nomen), serta penggunaan struktur yang tepat dalam penulisan kalimat pernyataan (Aussagaesatz), kalimat pertanyaan (Fragesatz) yang terdiri atas kalimat pertanyaan dengan tidak menggunakan kata tanya (Entscheidungsfrage) dan kalimat pertanyaan dengan menggunakan kata tanya (Ergänzungsfrage), serta kalimat perintah (Imperatisatz) . Sedangkan $6(21 \%)$ orang siswa memperoleh nilai pada interval skor $\geq 90$. Persentase nilai tersebut menunjukkan bahwa siswa sudah mampu menulis penulisan kata benda (Nomen), serta penggunaan struktur yang tepat dalam penulisan kalimat pernyataan (Aussagaesatz), kalimat pertanyaan (Fragesatz) yang terdiri atas kalimat pertanyaan dengan tidak menggunakan kata tanya (Entscheidungsfrage) dan kalimat pertanyaan dengan menggunakan kata tanya (Ergänzungsfrage), serta kalimat perintah (Imperatisatz).

Hasil analisis post-test pada kelas kontrol (XI IPA 3) dengan jumlah 29 orang siswa menunjukkan bahwa siswa yang memperoleh nilai pada masing-masing interval skor $\geq 80$ sebanyak 6 orang siswa, 76-79 sebanyak 11 orang siswa, 72-75 dan 68-71 sebanyak 4 orang siswa, 64-67 dan 60-63 sebanyak 2 orang siswa. Data tersebut menunjukkan bahwa terdapat 11 orang siswa yang memperoleh nilai di bawah standar kelulusan (75). Dengan kata lain $38 \%$ siswa memperoleh nilai di bawah standar tersebut disebabkan karena siswa masih keliru menulis penulisan kata benda (Nomen), serta penggunaan struktur yang tepat dalam penulisan kalimat pernyataan (Aussagaesatz), kalimat pertanyaan (Fragesatz) yang terdiri atas kalimat pertanyaan dengan tidak menggunakan kata tanya (Entscheidungsfrage) dan kalimat pertanyaan dengan menggunakan kata tanya (Ergänzungsfrage), serta kalimat perintah (Imperatisatz).

Kesulitan yang dialami siswa di atas sangat berbeda dengan pencapaian siswa setelah diajar melalui penggunaan media gambar puzzle. Hal tersebut dapat dilihat pada hasil analisis data post-test yang menunjukkan bahwa $100 \%$ siswa pada kelas eksperimen memperoleh nilai di atas standar minimal kelulusan untuk mata pelajaran bahasa Jerman, khususnya dalam keterampilan menulis. Pencapain tersebut juga menunjukkan bahwa siswa telah mampu menulis kata, frasa dan kalimat dengan huruf, ejaan dan tanda baca yang tepat. Selain itu, siswa juga telah mampu mengungkapkan informasi secara tertulis dalam kalimat sederhana sesuai konteks yang mencerminkan kecakapan menggunakan kata, frasa 
dan kalimat sesuai dengan ejaan, tanda baca dan struktur yang tepat.

Temuan penelitian ini yang menyatakan penggunaan media gambar puzzle efektif dalam keterampilan menulis kalimat sederhana bahasa Jerman siswa kelas XI IPA MAN 1 Makassar didukung oleh teori Ismail (2012:199) pada bab II mengemukakan bahwa puzzle adalah permainan yang menyusun suatu gambar atau benda yang telah dipecah dalam beberapa bagian. Puzzle sebagai media permainan tersebut ditambahkan oleh Buttner (2013:173) yang mengemukakan bahwa puzzle kosakata merupakan sarana yang sangat bermanfaat untuk mempelajari kembali kosakata, gramatikal, kebudayaan dan topik berdasarkan konten.

\section{KESIMPULAN}

Berdasarkan hasil analisis data yang telah diuraikan, dapat disimpulkan bahwa penggunaan media gambar puzzle efektif dalam keterampilan menulis kalimat sederhana bahasa Jerman siswa kelas XI IPA MAN 1 Makassar. Hal tersebut dibuktikan dari hasil analisis uji-t pada nilai post-test siswa setelah dilakukan uji-t pada masing-masing kelompok dengan hasil analisis data yaitu $t_{\text {hitung }}=$ 6,134> $t_{\text {tabel }}=2,003$ pada taraf signifikansi 0,05. Hasil analisis tersebut menunjukkan bahwa 100\% siswa pada kelas eksperimen memperoleh nilai di atas standar minimal kelulusan untuk mata pelajaran bahasa Jerman, khususnya keterampilan menulis. Pencapain kelulusan tersebut juga menunjukkan bahwa siswa telah mampu menulis kata, frasa dan kalimat dengan huruf, ejaan dan tanda baca yang tepat. Selain itu, siswa juga telah mampu mengungkapkan informasi secara tertulis dalam kalimat sederhana sesuai konteks yang mencerminkan kecakapan menggunakan kata, frasa dan kalimat sesuai dengan ejaan, tanda baca dan struktur yang tepat.Hal ini berarti bahwa ada perbedaan yang signifikan penggunaan media gambar puzzle dalam pembelajaran. Perbedaan yang signifikan tersebut menunjukkan bahwa penggunaan media gambar puzzle efektif dalam keterampilan menulis kalimat sederhana siswa kelas XI IPA MAN 1 Makassar.

\section{DAFTAR PUSTAKA}

Abbas, Saleh. 2006. Pembelajaran Bahasa Indonesia yang Efektif di Sekolah Dasar. Jakarta: Departemen Pendidikan Nasional.

Al-Azizi. 2010. Ragam Latihan Khusus Asah Ketajaman Otak Anak Plus Melejitkan Ingatannya. Jogjakarta: Diva Press

Anonim. 2006. Kurikulum KTSP (Kurikulum Tingkat Satuan Pendidikan) Bahasa Jerman.Jakarta: Depdikbud Balai Pustaka.

Arifin, E. Zainal dan S. Amran Tasai. 2010. Cermat Berbahasa Indonesia untuk Perguruan Tinggi. Jakarta: Akademika Pressindo. 
Arikunto, Suharsimi. 2013. Manajemen Penelitian. Jakarta: Rineka Cipta.

Arsyad, Azhar. 2014. Media Pembelajaran. Jakarta: PT Raja Grafindo Persada.

Buttner, Amy. 2013. Aktivitas Permainan dan Strategi Penilaian untuk Kelas Bahasa Asing. Jakarta: PT. Indeks.

Chaer, Abdul. 2006. Tata Bahasa Praktis Bahasa Indonesia. Jakarta: PT. Rineka Cipta.

Dalman. 2013. Penulisan Populer. Jakarta: PT. Raja Grafindo Persada.

Danim, Sudarwan. 2013. Media Komunikasi Pendidikan. Jakarta: PT Bumi Aksara.

Djiwandono, Soenardi. 2011. Tes Bahasa. Pegangan bagi Pengajar Bahasa. Edisi 2. Jakarta: Indeks.

Gie, The Liang. 2002. Terampil Mengarang. Yogyakarta: Andi.

Haerani. 2013. Kemampuan Menulis Kalimat Sederhana Bahasa Jerman melalui Media Gambar Siswa Kelas XI SMA Negeri 1 Bontonompo Kabupaten Gowa. Skripsi. Makassar: Universitas Negeri Makassar.

Ismail, Andang. 2012. Education Games. Yogyakarta: Pro-U Media.
Jamil, Sya'ban. 2012. 56 Games untuk Keluarga. Jakarta: Republika.

Jufri. 2002. Prinsip-Prinsip Strategi Pembelajaran Bahasa. Makassar: State University of Makassar Press.

Musfiqon. 2012. Pengembangan Media dan Sumber Pembelajaran. Jakarta: PT Prestasi Pustakaraya.

Nasaruddin, Nasmiati. 2011. Keefektifan Strategi Mencari Pasangan (Make a Match) dalam Pembelajaran Apresiasi Puisi Siswa Kelas XI SMKN 4 Jeneponto. Tesis. Makassar: Universitas Negeri Makassar.

Rahmanelli. 2007. "Efektivitas Pemerian Tugas Media Puzzle dalam Pembelajaran Geografi Regional." Jurnal Pelangi Pendidikan. Vol.2 (1): 23-30.

Sugiyono. 2010. Statistika untuk Penelitian. Bandung: Alfabeta.

Supardi. 2013. Aplikasi Statistika dalam Penelitian. Jakarta: Smart.

Sulistiyowati, Atik 2007. Efektivitas Penggunaan media film "hallo Aus Berlin" terhadap Kemampuan menulis Siswa kelas XI Bahasa di SMAN 7 Malang. Skripsi. FBS Malang. 